
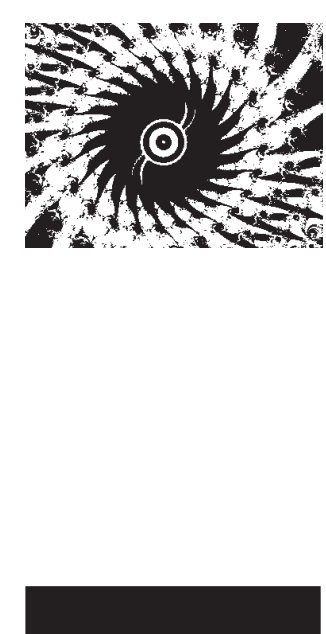

Neki dijelovi ovog rada nastali su kao dio istraživačkoga projekta "Analiza sustava zaposlenih u hrvatskom javnom sektoru", napravlienog za Maticu hrvatskih sindikata iz Zagreba.

\title{
KOMPARATIVNA ANALIZA ZAPOSLENOSTI I NAKNADA ZA ZAPOSLENE U JAVNOM SEKTORU U HRVATSKOJ I U EUROPSKOJ UNIJI
}

Predrag BEJAKOVIĆ, Vjekoslav BRATIĆ, Goran VUKŠIĆ Institut za javne financije, Zagreb

UDK: 35.08(497.5:4-6EU)

Prethodno priopćenje

Primljeno: 28. 10. 2010.

U članku se uspoređuje veličina javnoga sektora u Hrvatskoj u odnosu na zemlje Europske unije upotrebom više pokazatelia zaposlenosti u javnom sektoru (ti. njegovim pojedinim segmentima) te rashoda opće države. O podacima se diskutira s aspekta eventualno prevelikoga javnog sektora te u kratkoročnom kontekstu utjecaja recentne krize na zaposlenost i opću gospodarsku situaciju. Komparativna analiza pokazuje da, prema većini pokazatelja o zaposlenosti, Hrvatska nema prevelik javni sektor, osim kada je riječ o udjelu zaposlenih u javnim poduzećima u ukupnoj zaposlenosti. Udio rashoda opće države za naknade zaposlenika u Hrvatskoj niži je od prosjeka zemalja EU-a, ali je u prve tri godine promatranog razdoblja bio viši od istovjetnog udjela u zemljama Srednje i Istočne Europe. Udio ukupne potrošnje opće države u BDP-u za Hrvatsku niži je od istovjetnih udjela u zemljama EU-a i zemljama Srednje i Istočne Europe. Zbog utjecaja krize, u Hrvatskoj su donesene i/ili planirane neke restriktivne mjere $u$ pogledu plaća i zapošljavanja $u$ javnom sektoru. Uz nužnost zaustavljanja potencijalno neodrživih fiskalnih trendova, problemu zaposlenosti u javnom sektoru treba pristupiti stavljajući naglasak na povećanje učinkovitosti.

Ključne riječi: Hrvatska, zaposlenost, javni sektor, međunarodna usporedba

$\triangle \quad$ Predrag Bejaković, Institut za javne financije, Smičiklasova 


\section{UVOD I MOTIVACIJA}

U javno-političkim raspravama u Hrvatskoj raširena je teza o prevelikom broju zaposlenih $\mathrm{u}$ javnom sektoru te o prevelikim naknadama za te zaposlene $u$ odnosu na druge europske zemlje (vidi npr. Jutarnji list, 2010.a, 2010.b), pri čemu se često tvrdi da se time na dugi rok ograničava gospodarski rast, a u kratkoročnom kontekstu aktualne gospodarske krize ugrožava makroekonomska stabilnost zemlje. Cilj je ovog rada komparativna analiza zaposlenosti i naknada za zaposlene $u$ javnom sektoru u Hrvatskoj i zemljama Europske unije (EU) s aspekta dugoročno optimalne veličine javnoga sektora te $u$ kontekstu utjecaja recentne krize na zaposlenost i opću gospodarsku situaciju.

Načelno je optimalna veličina javnoga sektora u velikoj mjeri subjektivna stvar, tj. rezultat preferencija glasača izraženih kroz politički proces. Iako razne teorije ne daju jednoznačan konkretan odgovor na pitanje o poželjnim područjima djelovanja države, općenito se može reći da je djelovanje države potrebno onda kada tržišni mehanizam ne dovodi ni do kakvog, ili društveno poželjnog, ishoda, definiranog kroz politički proces u kojem do izražaja dolaze preferencije glasača (vidi npr. Nowotny, 1996., 90-91). Osim preferencija glasača, na veličinu javnoga sektora i razlike među zemljama utječu i brojni konkretni čimbenici. ${ }^{1} \mathrm{U}$ prvom redu važno je spomenuti empirijski potvrđenu tezu o povećanju udjela rashoda države u BDP-u s rastućim stupnjem razvitka države (mjereno BDP-om po glavi stanovnika). Može se reći da si bogatije države "mogu priuštiti" višu razinu javnih usluga, ali zbog raznih ideoloških opredjeljenja glasača uloga države (čak i među zemljama sličnoga stupnja razvoja) može jako varirati opsegom i strukturom aktivnosti. Nadalje, države se razlikuju i po političkoj organiziranosti; jesu li unitarne ili savezne. Može se pretpostaviti da će usluge javnoga sektora koje se pružaju na nižim razinama vlasti na bolji način zadovoljavati potrebe lokalnoga stanovništva, ali će to vjerojatno dovesti do većega broja zaposlenih u nižim tijelima vlasti, pa onda i u cjelokupnom državnom sektoru. Konačno, zemlje se uvelike razlikuju po veličini, demografskim i geografskim obilježjima, pa će npr. veći udio djece i mladih značiti veći broj zaposlenih osoba u predškolskim i obrazovnim ustanovama, dok će veći udio staračkoga stanovništva uvjetovati veće zapošljavanje u zdravstvenoj zaštiti i njezi, odnosno socijalnoj skrbi. Također, veća gustoća stanovništva omogućavat će učinkovitije pružanje pojedinih javnih usluga, jer se ponekad određena usluga pruža gotovo neovisno o broju korisnika. Općenito se može reći da pri pružanju (nekih) javnih usluga postoji ekonomija razmje- 
DRUŠ. ISTRAŽ. ZAGREB GOD. 21 (2012), BR. 1 (115)

STR. 101-119

BEJAKOVIĆ, P., BRATIĆ, V., VUKŠIĆ, G.: KOMPARATIVNA. ra, pa je udio države u gospodarstvu negativno povezan s veličinom zemlje (Alesina i Wacziarg, 1998.).

Budući da relevantna znanstvena literatura implicira postojanje optimalne veličine javnoga sektora, tj. upućuje na potencijalne negativne učinke prevelikoga javnog sektora na gospodarski rast (vidi npr. Barro, 1990.; Karras, 1997.; Pevcin, 2004.b; te posebno Magazzino i Forte, 2010. za recentan pregled) te na negativne efekte zapošljavanja u javnom sektoru (uz određene uvjete) na ukupnu zaposlenost (vidi npr. Algan i sur., 2002.; ili Gomes, 2010.), komparativnom analizom u ovom radu želi se ocijeniti relativna veličina hrvatskoga javnog sektora i eventualna potreba za smanjenjem područja djelovanja države u gospodarstvu.

U kontekstu aktualne ekonomske krize rasprava o ulozi države $u$ gospodarstvu primarno se fokusira na kratkoročne aspekte: potencijalno pozitivni anticiklički utjecaj povećane državne potrošnje, s jedne, te potencijalno ograničen fiskalni prostor, tj. problem financiranja postojećih ili povećanih javnih rashoda, s druge strane (Spilimbergo i sur., 2008.; IMF, 2010.). Istodobno, rashodi za zaposlene predstavljaju značajnu stavku javne potrošnje većine zemalja, od kojih mnoge u nadolazećem razdoblju ne mogu računati s razinom proračunskih prihoda iz ranijih razdoblja, pa su pritisnute teretom povećanog javnog duga prisiljene na fiskalne reforme, tj. fiskalnu konsolidaciju (Glassner, 2010.). Politikom zapošljavanja u javnom sektoru država može utjecati na zbivanja na tržištu rada, koja su često snažno pogođena aktualnom krizom. Iz ovoga proizlazi potreba za osvrtom na problematiku zaposlenosti u javnom sektoru Hrvatske te rashoda za te zaposlene i u kratkoročnom kontekstu utjecaja recentne ekonomske krize.

Ostatak rada strukturiran je kako slijedi: sljedeći ulomak sadrži definiciju i kratka metodološka objašnjenja mjerenja veličine javnoga sektora. Potom se daje međunarodna usporedba zaposlenosti i naknada za zaposlene u javnom sektoru u $\mathrm{Hr}$ vatskoj i zemljama EU-a, pri čemu se zaključci dopunjuju i usporedbom udjela ukupnih rashoda opće države u BDP-u. $\mathrm{U}$ četvrtom ulomku, s obzirom na rezultate komparativne analize, i nakon kratka osvrta na rezultate drugih relevantnih istraživanja, raspravlja se o argumentiranosti stavova dominantnih u javnim raspravama u kontekstu dugoročnije politike zapošljavanja i politike plaća u javnom sektoru te o problemima s kojima se suočavaju nositelji ekonomske politike u kontekstu potrebe smanjenja fiskalnih rashoda (između ostalih i rashoda za zaposlene) i želje da se državnom potrošnjom privremeno ipak agregatna potražnja održi na što višoj razini i time ublaži negativne posljedice krize. Zadnji ulomak sadrži sažetak zaključaka. 


\section{DEFINICIJA I MJERENJE VELIČINE JAVNOGA SEKTORA}

Na početku treba definirati zaposlenost $\mathrm{u}$ javnom sektoru, $\mathrm{tj}$. sâm javni sektor. Pri tome se držimo pristupa Međunarodne organizacije rada (ILO - International Labour Organization), a koji polazi od koncepta definiranog prema Sustavu nacionalnih računa Ujedinjenih naroda iz 1993. godine (Hammouya, 1999.). Prema tom konceptu, javni sektor čine opća država i javna poduzeća. Sektor opće države sastoji se od "ukupnosti institucionalnih jedinica, koje, osim ispunjavanja svoje političke odgovornosti i uloge u ekonomskom reguliranju, pružaju načelno netržišne usluge (i moguća dobra) za osobnu i zajedničku potrošnju, te preraspodjeljuju dohodak i bogatstvo" (UN 1993., članak 2.20). Opća država obuhvaća: (a) sve jedinice središnje, regionalne i lokalne vlasti; (b) sve fondove socijalnog osiguranja na svim razinama vlasti; (c) sve netržišne neprofitne institucije kontrolirane i većim dijelom financirane od strane jedinica vlasti. Nisu obuhvaćena javna poduzeća (financijska i nefinancijska) koja se, kao dodatni segment javnoga sektora, definiraju kao "rezidentne korporacije i kvazikorporacije kontrolirane od državnih jedinica, pri čemu je kontrola definirana kao mogućnost određivanja opće korporativne politike odabirom prikladnih direktora, ako bude potrebno" (UN 1993., članak 4.72 i 4.84).

Usprkos općeprihvaćenoj temeljnoj definiciji javnoga sektora prema Sustavu nacionalnih računa, do razlika među zemljama pri određivanju granice između privatnoga i javnoga sektora često dolazi zbog različite operacionalizacije gornje definicije. Također, postoje problemi i u jednoznačnom i preciznom mjerenju relativne veličine i značaja državnih djelatnosti u gospodarstvu (vidi npr. Zimmermann i Henke, 1994., 22-29). Vjerojatno najčešći pokazatelj u relevantnoj literaturi jest udio rashoda opće države u BDP-u. Njime, međutim, nije obuhvaćen sektor javnih poduzeća, koji se može obuhvatiti korištenjem udjela zaposlenih $\mathrm{u}$ javnom sektoru u ukupnoj zaposlenosti. Treba naglasiti da ocjena uloge države u gospodarstvu upotrebom ovih (ili drugih) pojedinačnih pokazatelja može biti problematična zato što se svi oblici državnoga djelovanja ne moraju jednako odražavati na rashode države (kao npr. regulatorna uloga države), ${ }^{2} \mathrm{i} / \mathrm{ili}$ biti jednako radno-intenzivni. Tako se npr. države mogu razlikovati i prema načinu pružanja usluga, tj. tradiciji i razini podugovaranja s privatnim sektorom. Ako javni sektor organizira i financira pojedinu uslugu, to ne znači nužno da je sâm i pruža, nego to može podugovoriti s privatnim sektorom (Drewry, 1999.). U zemljama koje imaju razvijen sustav podugovaranja u pružanju javnih usluga, udio zaposlenih u javnom sektoru bit će manji (ceteris paribus). ${ }^{3}$ Međutim, iako se podugovaranjem smanjuje broj za- 
poslenih $\mathrm{u}$ javnom sektoru, ukupan broj zaposlenih koji ostvaruju neki javni program ili pružaju javnu uslugu ne mora nužno biti manji, pa će se tako organizirane usluge države neizbježno odraziti na proračunske rashode.

\section{MEĐUNARODNA USPOREDBA ZAPOSLENOSTI I NAKNADA ZA ZAPOSLENE U JAVNOM SEKTORU}

U ovom se dijelu rada uspoređuje veličina hrvatskoga javnog sektora u odnosu na javne sektore zemalja EU-a (mjereno udjelom zaposlenih u javnom sektoru u ukupnom broju zaposlenih); visina proračunskih rashoda opće države za naknade zaposlenima (mjereno udjelom tih rashoda $\mathrm{u}$ BDP-u) te se navode i neka opažanja o veličini javnoga sektora mjerenoj udjelom ukupnih rashoda opće države u BDP-u. Razlozi su navedeni u prethodnom ulomku. Uz odgovarajući pokazatelj za Hrvatsku i pojedine zemlje EU-a, u tablicama je prikazan i prosječni pokazatelj za zemlje EU-a, ali posebno i prosjek za zemlje Središnje i Istočne Europe (SIE), koje su po glavnim značajkama sličnije Hrvatskoj.

\section{Usporedba zaposlenosti u javnom sektoru}

Najvažniji međunarodno prihvaćeni koncept javnoga sektora sadržan je u spomenutom i opisanom Sustavu nacionalnih računa UN-a. ILO, podaci kojega se u nastavku prikazuju, u svojim se aktivnostima drži toga koncepta, pa je javni sektor podijeljen na opću državu i sektor javnih poduzeća. Međutim, podaci koje ILO uspijeva prikupiti za neke zemlje nisu uvijek kvalitetni, što iznenađuje s obzirom na značaj zaposlenosti u javnom sektoru za svako gospodarstvo (Hoffmann, 2002.). U radnim materijalima Statističkog ureda ILO-a, Hammouya (1999.) opisuje metodologiju mjerenja i podatke o strukturi i trendovima zaposlenosti $\mathrm{u}$ javnom sektoru raznih zemalja, pri čemu zamjećuje nedostatnu kvalitetu i usporedivost podataka uglavnom zbog postojanja najmanje dviju nacionalnih institucija koje pripremaju statistike o zaposlenosti u javnom sektoru u većini zemalja; postojanja raznih vrsta izvora podataka unutar mnogih od tih institucija; djelomično proizvoljnog odabira kriterija definicije javnih institucija te ponekad neuključivanja svih vrsta poslova i/ili oblika zapošljavanja; nedostatnoga korištenja posebnih anketa o zaposlenosti u javnom sektoru u većini zemalja itd.

U interpretaciji podataka ILO-a potreban je stoga povećan oprez. Zato se uz te podatke u ovom ulomku analiziraju i podaci o jednom segmentu zaposlenih u općoj državi, tj. zaposleni na području Javne uprave i obrane, obveznog socijalnog osiguranja, prema NKD-u, čiji je obuhvat jedinstven $u$ svim zemljama (izvor ovih podataka je Eurostat), uz nedosta- 
DRUŠ. ISTRAŽ. ZAGREB GOD. 21 (2012) BR. 1 (115),

STR. 101-119

BEJAKOVIĆ, P., BRATIĆ V., VUKŠIĆ, G.: KOMPARATIVNA... tak da ti podaci pokazuju ukupnu zaposlenost po područjima NKD-a, ne dijeleći ih na zaposlenike u privatnom i javnom sektoru. ${ }^{4}$ Za Hrvatsku su nam ipak dostupni neki detaljniji podaci iz publikacija Državnog zavoda za statistiku (DZS). Tako je u Hrvatskoj 2008. godine u navedenom području NKD-a bilo zaposleno 19,4\% svih zaposlenika u kategoriji: državni sektor i sektor u pretvorbi (DZS, 2009., Tablica 6-19), a koja odgovara kategoriji javnoga sektora, tj. općoj državi i javnim poduzećima za Hrvatsku u podacima ILO-a. 5 Također, od ukupnoga broja zaposlenih $\mathrm{u}$ pravnim osobama u navedenom području NKD-a, na zaposlenike pravnih osoba u državnom vlasništvu otpada 99,7\% (vlastiti izračun na temelju podataka DZS-a, 2009., Tablica 6-2). Sljedeća tablica sadrži podatke o zaposlenosti u javnom sektoru za Republiku Hrvatsku između 2005. i 2008. godine te usporedbu s prosjekom zemalja EU-a za koje su odgovarajući podaci bili dostupni. ${ }^{6}$ U lijevom dijelu tablice prikazani su (međunarodno potpuno usporedivi) podaci o ukupnom broju zaposlenih u području Javne uprave i obrane, obveznog socijalnog osiguranja, u srednjem dijelu su podaci o zaposlenosti u sektoru opće države, dok desni dio sadrži podatke o zaposlenima u javnim poduzećima.7

Hrvatska je tijekom promatranog razdoblja imala prosječni udio zaposlenih u području Javne uprave i obrane, obveznog socijalnog osiguranja, u ukupnoj zaposlenosti od 6,04\%, pri čemu je najveća vrijednost od 6,38\% zabilježena u 2005. godini, a najniža od $5,75 \%$ na kraju razdoblja. U svakoj promatranoj godini istovjetni prosječni udio za zemlje EU-a bio je viši i iznosio je između 6,95 i 7,12\%. U isto vrijeme, u svim promatranim godinama, zemlje SIE bilježe nešto niže udjele od prosjeka EU-a, ali više od Hrvatske (između 6,34 i 6,57\%).

Prosječan udio zaposlenih u sektoru opće države u ukupnoj zaposlenosti, za zemlje EU-a za koje su podaci dostupni, kretao se između $19,07 \%$ u 2008 . i $20,88 \%$ na početku promatranog razdoblja. Hrvatska je u promatranom razdoblju imala prosječni udio od $17,15 \%$, što je značajno manje od prosjeka EU-a. Tijekom istog razdoblja, prosječne vrijednosti za zemlje SIE iznosile su između 18,5\% u 2007. godini i 20,45\% u 2005. godini. Treba napomenuti da prosječni udio zaposlenih u sektoru opće države u zemljama SIE, a koje su sličnije Hrvatskoj po stupnju gospodarskog razvoja, ali i po tranziciji iz planskoga gospodarstva u tržišno, nije puno niži od prosjeka zemalja EU-a, tj. u 2008. godini bio je i viši. S obzirom na to da su zemlje SIE (u prosjeku) slabije razvijene od drugih članica EU-a, to je neočekivano. Međutim, uzevši u obzir povijesni ekonomski kontekst tih zemalja, ovakav razvoj može biti posljedica uvriježenih preferencija glasača za višu razinu usluga države. 


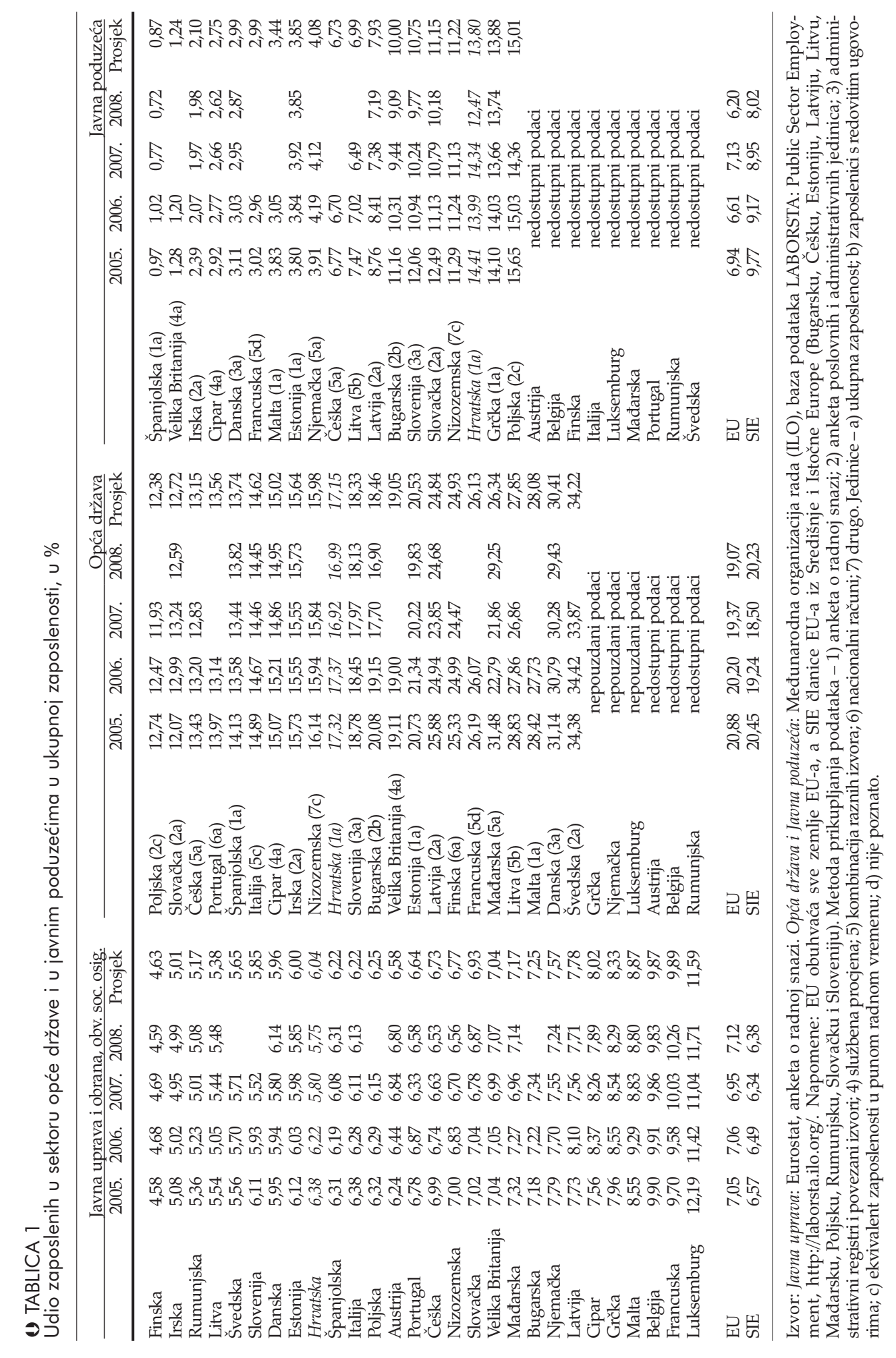


DRUŠ. ISTRAŽ. ZAGREB GOD. 21 (2012),

BR. 1 (115)

STR. 101-119

BEJAKOVIĆ, P., BRATIĆ V., VUKŠIĆ, G.: KOMPARATIVNA.
Kada je riječ o udjelu zaposlenih u javnim poduzećima u ukupnoj zaposlenosti zemalja EU-a za koje su bili dostupni podaci i u Hrvatskoj, tijekom promatranoga razdoblja od 2005. do 2008. prosječan udio za zemlje EU-a iznosio je između 6,20 i 7,13\%. U usporedbi s drugim zemljama, ovaj je udio značajno viši u Hrvatskoj: tijekom promatrane četiri godine iznosio je u prosjeku 13,8\% (u istovjetnom udjelu prednjače tek Grčka i Poljska). Budući da razne zemlje mogu imati drugačije definicije javnih poduzeća, ovdje je potrebno posebno naglasiti potencijalne probleme nepotpune usporedivosti podataka. Kada je riječ o zemljama SIE, vidi se da je udio zaposlenih $\mathrm{u}$ javnim poduzećima tih zemalja viši nego u ostalim zemljama EU-a, što može biti odraz još nedovršenoga procesa privatizacije. Međutim, udio zaposlenih u Hrvatskoj značajno je viši od prosjeka i za tu grupu zemalja.

Važno je dodati nekoliko napomena o zaposlenosti na drugim područjima NKD-a, u kojima većinu zaposlenih čine zaposlenici javnoga sektora, osim prikazanog područja Javne uprave i obrane; obveznog socijalnog osiguranja. Tako je u Hrvatskoj 2008. godine na području Obrazovanja zaposleno 17,8\% svih zaposlenika u kategoriji: državni sektor i sektor u pretvorbi (DZS, 2009., Tablica 6-19). Osim toga, velik dio zaposlenika javnoga sektora radi u područjima NKD-a: Zdravstvena zaštita i socijalna skrb 15,2\%; Ostale društvene, socijalne i osobne uslužne djelatnosti 6,5\%. Ova tri područja NKD-a, zajedno s područjem Javna uprava i obrana, obvezno socijalno osiguranje, obuhvaćaju 58,9\% svih zaposlenih u javnom sektoru. $\mathrm{S}$ druge strane, od ukupnoga broja zaposlenih u pravnim osobama $u$ navedenim područjima NKD-a na zaposlenike pravnih osoba u državnom vlasništvu otpadaju sljedeći udjeli (vlastiti izračun na temelju podataka DZS-a, 2009., Tablica 6-2): Obrazovanje 94,3\%; Zdravstvena zaštita i socijalna skrb 85,7\%; Ostale društvene, socijalne i osobne uslužne djelatnosti $57,2 \%$. Iako zbog uštede na prostoru pojedinačni podaci za zemlje EU-a o zaposlenosti u ova tri područja NKD-a nisu prikazani, nužno je spomenuti da, kada je riječ u udjelima zaposlenih na području Obrazovanja u ukupnoj zaposlenosti, Hrvatska ima relativno malen udio s prosjekom od samo $5,62 \%$ u promatranom razdoblju. Za zemlje EU-a, prosječni udjeli iznosili su između 7,14 i 7,4\%. Prosjek za deset zemalja SIE viši je od prosjeka EU-a, pa time i od hrvatskoga prosjeka. Nadalje, usporedba udjela zaposlenih na području Zdravstvene zaštite i socijalne skrbi pokazuje da se prosjek promatranih zemalja EU-a kretao između 8,7 i 8,87\% od 2005. do 2008., dok je u Hrvatskoj u prosjeku na ovom području bilo zaposleno 5,49\% ukupno zaposlenih. Dakle, i po ovom kriteriju Hrvatska je značajno ispod prosjeka EU-a. Isto vrijedi i za ostale zemlje SIE, koje ipak imaju nešto više udjele nego Hr- 
DRUŠ. ISTRAŽ. ZAGREB GOD. 21 (2012), BR. 1 (115)

STR. 101-119

BEJAKOVIĆ, P., BRATIĆ V., VUKŠIĆ, G.: KOMPARATIVNA.. vatska. Kada je riječ o udjelu zaposlenosti na području Ostalih društvenih, socijalnih i osobnih uslužnih djelatnosti, on je u Hrvatskoj nešto bliži prosjeku zemalja EU-a nego na prethodnim područjima, ali je još uvijek niži. Tako je u Hrvatskoj iznosio 4,19\%, dok se za zemlje EU-a kretao između 4,38 i $4,44 \%$. U usporedbi sa zemljama SIE udjeli za Hrvatsku nešto su viši.

Budući da država, tj. javni sektor, velik dio svojih usluga mora pružati svim stanovnicima neke zemlje, osim udjela zaposlenih u pojedinim djelatnostima u ukupnoj zaposlenosti, važni su i udjeli zaposlenih na ovim područjima djelatnosti u ukupnoj populaciji. S obzirom na to da Hrvatska ima relativno nisku stopu ukupne zaposlenosti, relevantni udjeli zaposlenih u javnom sektoru u ukupnoj populaciji još su niži u odnosu na druge zemlje nego udjeli u ukupnoj zaposlenosti. Iz navedenog možemo zaključiti da prema usporedbi sa zemljama EU-a, Hrvatska ima ispodprosječan udio zaposlenih na ovim područjima u ukupnoj zaposlenosti (ali i u populaciji). Gotovo isti zaključak vrijedi i u usporedbi sa deset zemalja Srednje i Istočne Europe, osim za područje Ostalih društvenih, socijalnih i osobnih uslužnih djelatnosti.

\section{Usporedba rashoda za naknade zaposlenima i ukupnih rashoda opće konsolidirane države}

U ovom dijelu prikazuje se visina rashoda opće države za naknade zaposlenima te ukupnih rashoda opće države u Hrvatskoj u odnosu na zemlje EU-a, mjereno udjelom u BDP-u. Podaci su međunarodno usporedivi.

Iz lijevoga dijela Tablice 2 vidi se da je prosječan udio rashoda proračuna opće države za naknade zaposlenima u zemljama EU-a (od 2005. do 2008.) varirao između 10,73 i 11,15\% BDP-a. Za Hrvatsku je prosječna vrijednost udjela tijekom istog razdoblja iznosila $9,92 \%$, a za svaku je promatranu godinu bila niža od prosjeka zemalja EU-a. Iz toga bi se moglo zaključiti da rashodi za naknade zaposlenima opće države ne predstavljaju za porezne obveznike u Hrvatskoj veći teret, od odgovarajućega prosječnog tereta u drugim europskim zemljama, mjereno udjelom u BDP-u. Međutim, u usporedbi sa zemljama Srednje i Istočne Europe, vidi se da je udio rashoda za naknade zaposlenima u BDP-u u Hrvatskoj nešto viši od prosjeka za tu skupinu zemalja, osim u 2008. godini, kada dolazi do značajnoga povećanja prosječnog udjela za te zemlje. Podatak je posebno zanimljiv ako se prisjetimo Tablice $1 \mathrm{i}$ informacije da je udio zaposlenih u sektoru opće države u ukupnom broju zaposlenih za te zemlje nešto viši nego u Hrvatskoj. Treba naglasiti da se ova usporedba odnosi samo na one naknade za zaposlene koje se isplaćuju iz proračuna opće države. U Tablici 2 prikazan je podatak i za 2009. godinu, iz ko- 
(1) TABLICA 2

Udio naknada zaposlenima i ukupnih rashoda opće konsolidirane države u BDP-u, u \% jeg bi se mogao očitati utjecaj krize. Naime, gotovo sve promatrane zemlje iskusile su pad BDP-a u toj godini, pa su se relevantni omjeri mogli značajno promijeniti, prije svega ovisno o intenzitetu smanjenja BDP-a (budući da su zaposlenost i plaće u javnom sektoru obično rigidni). U gotovo svim zemljama (osim u Latviji, Mađarskoj i na Malti) došlo je do povećanja udjela rashoda za naknade zaposlenima u BDP-u. Udio za Hrvatsku ostaje značajno niži od prosjeka EU-a te nešto niži i od prosjeka zemalja Srednje i Istočne Europe. ${ }^{8}$

\begin{tabular}{|c|c|c|c|c|c|c|c|c|c|c|c|c|c|}
\hline & \multicolumn{7}{|c|}{ Naknade za zaposlene } & \multicolumn{6}{|c|}{ Ukupni rashodi } \\
\hline & 2005. & 2006. & 2007. & 2008. & rosjek & 2009. & & 2005. & 2006. & 2007. & 2008. & Prosjek & 2009. \\
\hline Slovačka & 7,30 & 7,40 & 6,80 & 6,60 & 7,03 & 7,80 & Litva & 33,30 & 33,60 & 34,80 & 37,40 & 34,78 & 43,00 \\
\hline Njemačka & 7,50 & 7,20 & 6,90 & 6,90 & 7,13 & 7,40 & Estonija & 33,60 & 34,00 & 34,80 & 39,90 & 35,58 & 45,40 \\
\hline Luksemburg & 7,90 & 7,30 & 7,10 & 7,10 & 7,35 & 7,90 & Rumunjska & 33,50 & 35,30 & 36,00 & 37,60 & 35,60 & 40,40 \\
\hline Češka & 8,00 & 7,80 & 7,60 & 7,60 & 7,75 & 8,10 & Slovačka & 38,00 & 36,90 & 34,40 & 34,80 & 36,03 & 40,80 \\
\hline Bugarska & 9,80 & 9,00 & 9,00 & 9,00 & 9,20 & 9,70 & Irska & 33,90 & 34,40 & 36,60 & 42,00 & 36,73 & 48,40 \\
\hline Rumunjska & 8,70 & 9,10 & 9,30 & 10,00 & 9,28 & 10,60 & Latvija & 35,60 & 38,10 & 35,70 & 38,60 & 37,00 & 42,90 \\
\hline Nizozemska & 9,60 & 9,30 & 9,20 & 9,10 & 9,30 & 10,00 & Hrvatska & 38,02 & 37,62 & 37,80 & 38,07 & 37,88 & 39,77 \\
\hline Austrija & 9,40 & 9,40 & 9,20 & 9,20 & 9,30 & 9,80 & Luksemburg & 41,50 & 38,30 & 36,20 & 37,20 & 38,30 & 42,40 \\
\hline Poljska & 10,00 & 9,80 & 9,60 & 10,00 & 9,85 & 10,20 & Bugarska & 39,30 & 36,50 & 41,50 & 37,30 & 38,65 & 40,70 \\
\hline Hrvatska & 10,09 & 9,85 & 9,90 & 9,83 & 9,92 & 10,58 & Španjolska & 38,40 & 38,40 & 39,20 & 41,10 & 39,28 & 45,90 \\
\hline Estonija & 9,90 & 9,40 & 9,80 & 11,40 & 10,13 & 12,90 & Cipar & 43,60 & 43,40 & 42,20 & 42,60 & 42,95 & 46,40 \\
\hline Španjolska & 10,00 & 10,00 & 10,20 & 10,80 & 10,25 & 11,80 & Poljska & 43,40 & 43,90 & 42,20 & 43,30 & 43,20 & 44,50 \\
\hline Irska & 9,80 & 9,90 & 10,20 & 11,20 & 10,28 & 12,10 & Češka & 45,00 & 43,70 & 42,50 & 42,90 & 43,53 & 46,10 \\
\hline Litva & 10,30 & 10,40 & 9,90 & 10,80 & 10,35 & 12,70 & Malta & 44,80 & 43,70 & 42,40 & 44,80 & 43,93 & 44,30 \\
\hline Latvija & 10,00 & 10,00 & 10,60 & 12,00 & 10,65 & 11,90 & Slovenija & 45,20 & 44,50 & 42,40 & 44,30 & 44,10 & 49,90 \\
\hline Italija & 11,00 & 11,00 & 10,60 & 10,80 & 10,85 & 11,30 & Grčka & 43,80 & 43,20 & 45,00 & 46,80 & 44,70 & 50,40 \\
\hline Slovenija & 11,50 & 11,20 & 10,50 & 11,10 & 11,08 & 12,60 & Njemačka & 46,80 & 45,40 & 43,70 & 43,70 & 44,90 & 47,60 \\
\hline Velika Britanija & 11,30 & 11,30 & 11,00 & 11,00 & 11,15 & 12,10 & Velika Britanija & 44,10 & 44,30 & 44,20 & 47,40 & 45,00 & 51,50 \\
\hline Grčka & 11,50 & 11,10 & 11,20 & 11,50 & 11,33 & 12,40 & Nizozemska & 44,80 & 45,50 & 45,50 & 45,90 & 45,43 & 51,60 \\
\hline Belgija & 12,00 & 11,90 & 11,70 & 12,10 & 11,93 & 12,80 & Portugal & 47,60 & 46,30 & 45,80 & 46,10 & 46,45 & 51,00 \\
\hline Mađarska & 12,60 & 12,20 & 11,50 & 11,60 & 11,98 & 11,20 & Italija & 48,20 & 48,70 & 47,80 & 48,80 & 48,38 & 51,90 \\
\hline Francuska & 13,20 & 13,00 & 12,80 & 12,70 & 12,93 & 13,20 & Finska & 50,20 & 49,00 & 47,30 & 49,50 & 49,00 & 56,10 \\
\hline Finska & 13,80 & 13,50 & 12,90 & 13,40 & 13,40 & 14,90 & Austrija & 50,20 & 49,50 & 48,70 & 49,00 & 49,35 & 51,80 \\
\hline Portugal & 14,40 & 13,60 & 12,90 & 12,90 & 13,45 & 13,70 & Belgija & 52,20 & 48,60 & 48,40 & 50,00 & 49,80 & 54,20 \\
\hline Malta & 14,00 & 13,30 & 12,90 & 14,60 & 13,70 & 14,50 & Mađarska & 50,10 & 52,00 & 49,80 & 49,20 & 50,28 & 49,80 \\
\hline Cipar & 14,70 & 14,70 & 14,20 & 14,10 & 14,43 & 15,60 & Danska & 52,80 & 51,60 & 50,90 & 51,80 & 51,78 & 58,70 \\
\hline Švedska & 15,60 & 15,40 & 15,20 & 15,00 & 15,30 & 15,50 & Francuska & 53,40 & 52,70 & 52,30 & 52,80 & 52,80 & 55,60 \\
\hline Danska & 17,30 & 17,00 & 16,80 & 17,20 & 17,08 & 19,40 & Švedska & 53,90 & 53,50 & 52,00 & 52,50 & 52,98 & 55,80 \\
\hline EU & 11,15 & 10,93 & 10,73 & 11,10 & & 11,93 & EU & 43,97 & 43,52 & 43,05 & 44,34 & & 48,41 \\
\hline SIE & 9,81 & 9,63 & 9,46 & 10,01 & & 10,77 & SIE & 39,70 & 39,85 & 39,41 & 40,53 & & 44,35 \\
\hline
\end{tabular}

Izvor: Eurostat, Ministarstvo financija RH, DZS.

Napomena: EU27 obuhvaća sve zemlje EU-a, a SIE10 članice EU-a iz Središnje i Istočne Europe (Bugarsku, Češku, Estoniju, Latviju, Litvu, Mađarsku, Poljsku, Rumunjsku, Slovačku i Sloveniju).

U desnom dijelu Tablice 2 prikazana je usporedba udjela ukupnih rashoda opće države u BDP-u. Kao što je već spomenuto, država neke usluge može pružati sama, tj. uz pomoć zaposlenih u javnom sektoru, a može i podugovoriti pružanje istih usluga s privatnim sektorom. Valja očekivati da će države koje u većoj mjeri same pružaju usluge imati i veći broj zaposlenika u javnom sektoru (ceteris paribus) nego zemlje koje češće pribjegavaju podugovaranju s privatnim sektorom. Međutim, financiranje takve potrošnje kroz podugovaranje znači teret za porezne obveznike, kao i financiranje plaća za- 
DRUŠ. ISTRAŽ. ZAGREB GOD. 21 (2012),

BR. 1 (115)

STR. 101-119

BEJAKOVIĆ, P., BRATIĆ V., VUKŠIĆ, G.: KOMPARATIVNA. poslenih $\mathrm{u}$ javnom sektoru, pa je potrebno usporediti i ukupne rashode proračuna. Prosječni udio ukupnih rashoda opće države u BDP-u za Hrvatsku od 2005. do 2008. iznosio je 37,88\% i bio je niži od prosjeka zemalja EU-a (između 43,05 i 44,34\%), ali i od prosjeka zemalja Srednje i Istočne Europe (između 39,7 i 40,53\%), i to u svakoj promatranoj godini. U 2009. godini, kao rezultat krize, taj je udio porastao u gotovo svim promatranim zemljama. U Hrvatskoj je još uvijek bio niži od prosjeka EU27 i deset zemalja SIE, i to osjetnije nego u ranijim godinama. Može se zaključiti da financiranje javnih usluga u Hrvatskoj ne predstavlja veći teret (mjereno udjelom u BDP-u) od istovjetnoga prosječnog tereta u zemljama EU-a i SIE.

\section{DISKUSIJA USPOREDBE IZ PERSPEKTIVE REZULTATA RELEVANTNIH ISTRAŽIVANJA}

\section{Dugoročniji aspekti}

Prema rezultatima mnogih istraživanja, posljedice zapošljavanja u javnom sektoru na ukupnu zaposlenost mogu biti negativne, jer, u određenim okolnostima, mogu istisnuti više radnih mjesta $u$ privatnom sektoru nego što ih se stvara $u$ javnom. Tako npr. Algan i sur. (2002.), na temelju teoretskoga modela i njegova empirijskog testa na primjeru zemalja OECD-a, pokazuju da stvaranje 100 radnih mjesta $\mathrm{u}$ javnom sektoru može umanjiti zaposlenost $u$ privatnom za čak 150 zaposlenih, dovodi do laganog smanjenja ukupne participacije radne snage te povećava broj nezaposlenih za 33. Međutim, prema njihovim rezultatima, ovakvo istiskivanje znakovito je samo u zemljama u kojima se usluge koje pruža javni sektor u velikoj mjeri mogu zamijeniti uslugama privatnog sektora te $\mathrm{u}$ kojima javni sektor nudi atraktivnije uvjete zapošljavanja (plaće i druge beneficije) nego privatni sektor. Do usporedivih i komplementarnih rezultata dolazi i Gomes (2010.) kalibriranjem dinamičkoga stohastičkog modela. On pronalazi da više plaće u javnom sektoru povećavaju ukupnu nezaposlenost, dok preniske plaće dovode do problema u pronalasku radnika u javnom sektoru. Izračunava da je optimalno imati do 3\% niže plaće u javnom sektoru (u osnovnom scenariju), jer su ta radna mjesta sigurnija, ali i sâm navodi da sve studije pokazuju da u stvarnosti postoji premija za zaposlenike javnoga sektora u obliku više plaće.

$S$ obzirom na rezultate komparativne analize u prethodnom ulomku, čini se da su u Hrvatskoj potencijalni problemi koje povećana zaposlenost $\mathrm{u}$ javnom sektoru može izazvati manje izraženi nego u zemljama EU-a, uključujući i zemlje SIE, kada je riječ o zaposlenima u sektorima javne uprave, obrane i obveznoga socijalnog osiguranja te zdravstva i obrazovanja, 
DRUŠ. ISTRAŽ. ZAGREB

BR. 1 (115),

STR. 101-119

BEJAKOVIĆ, P., BRATIĆ V., VUKŠIĆ, G.: KOMPARATIVNA... GOD. 21 (2012),

na relativno velik udio zaposlenih u javnim poduzećima, potencijalno negativni efekti na privatni sektor u Hrvatskoj mogu se očekivati poglavito $u$ zapošljavanju $u$ ovom segmentu javnoga sektora, posebno ako se uzme $\mathrm{u}$ obzir da se djelatnosti koje obavljaju javna poduzeća zasigurno u većoj mjeri mogu obavljati i iz privatnoga sektora. Kod usporedbe naknada za zaposlene opće države slika je manje optimistična, jer Hrvatska stoji gore nego kod usporedbe broja zaposlenih u općoj državi, posebno u odnosu na zemlje SIE. Također, kako navodi Nestić (2005.), u Hrvatskoj postoji premija za zaposlene $\mathrm{u}$ javnom sektoru u prosječnom iznosu od otprilike $9 \% .9$ Iako nemamo usporedive podatke za druge zemlje, ove dvije činjenice impliciraju da su vjerojatno potrebne promjene $u$ politici plaća za zaposlenike opće države.

U kontekstu teorijske rasprave o optimalnoj ulozi države u gospodarstvu, mjerene udjelom rashoda opće države u BDP-u, središnju poziciju zauzima tzv. "Barrovo pravilo", prema kojem je razina usluga države optimalna, u okviru endogenoga modela rasta, ako je granični proizvod državnih usluga jednak jedan (Barro, 1990.; Karras, 1997.). Postoje mnoge empirijske studije koje pokušavaju utvrditi optimalnu razinu djelovanja države u gospodarstvu, pri čemu je posebno zanimljiv recentan rad Magazzinija i Fortea (2010.), u kojem se procjenjuju optimalni udjeli za zemlje EU-a te posebno za zemlje Srednje i Istočne Europe (tj. skupinu zemalja koje u ovom radu svrstavamo u tu grupu - zemlje SIE). Njihovi rezultati pokazuju da je stvarni udio potrošnje opće države u BDP-u viši od procijenjenoga optimalnog udjela za nekih $10 \%$ za sve zemlje EU27. Za 12 zemalja "starih" članica EU-a, za koje je bilo moguće procijeniti pojedinačne optimalne udjele, razlike se kreću od 5,7\% za Njemačku do čak $18,1 \%$ za Belgiju. Za zemlje SIE, procijenjeni optimalni udio iznosi oko $40 \%$, što je nešto više od $4 \%$ iznad prosjeka stvarnog udjela u tim zemljama u 2009. godini. Istodobno, odgovarajući udio za Hrvatsku u istoj godini iznosi $39,77 \%$, pa uz pretpostavku da procjena optimalnog udjela potrošnje države u BDP-u u zemljama SIE iz Magazzini i Forte (2010.) vrijedi i za Hrvatsku, možemo reći da je relevantan udio u Hrvatskoj gotovo istovjetan s optimalnim. 10

\section{Kratkoročni kontekst gospodarske krize}

Što se tiče optimalne reakcije javnoga sektora na promjene $u$ poslovnim ciklusima, Gomes (2010.) utvrđuje da je prociklična politika plaća $u$ javnom sektoru optimalna, tj. da dovodi do stabilizacije stope nezaposlenosti. Stoga bi plaće u javnom sektoru trebale pratiti plaće u privatnom sektoru. Isto ne vrijedi i za otvaranje novih radnih mjesta $u$ javnom sektoru, $\mathrm{tj}$. politiku zapošljavanja, koja bi trebala biti anticiklična. Ovisno 
DRUŠ. ISTRAŽ. ZAGREB GOD. 21 (2012), BR. 1 (115)

STR. 101-119

BEJAKOVIĆ, P., BRATIĆ V., VUKŠIĆ, G.: KOMPARATIVNA.. o vrsti šoka, moguće je da dodatno zapošljavanje u javnom sektoru smanji ili poveća stopu nezaposlenosti, dok smanjenje odlazaka s radnih mjesta u javnom sektoru u svakom slučaju umanjuje nezaposlenost. U ovom kontekstu važno je spomenuti studiju Finn (1998.), koja, u okviru kvantitativnog modela realnih poslovnih ciklusa gospodarstva SAD-a, pronalazi da šokovi vezani uz potrošnju države na zaposlene u javnom sektoru različito utječu na zaposlenost i proizvodnju privatnoga sektora, od fiskalnih šokova koji proizlaze iz promjene državne potrošnje na robe i usluge privatnog sektora. Dok povećana potrošnja na kupnju dobara i usluga ima ekspanzivni učinak na gospodarstvo, povećana potrošnja na zaposlene utječe negativno. Međutim, u novijem radu Linnemann (2009.), također uz pomoć podataka za SAD, pronalazi empirijske dokaze jednakoga smjera utjecaja ovih vrsta fiskalnih šokova, pa zaključuje da postoji pozitivan privremeni utjecaj zaposlenosti u javnom sektoru na zaposlenost u privatnom sektoru. ${ }^{11}$ Međutim, i uz pretpostavku pozitivnog učinka povećane zaposlenosti u javnom sektoru, ili povećane državne potrošnje na gospodarstvo, optimalna reakcija fiskalne politike na krizu može biti, i u velikom broju zemalja i jest, ograničena fiskalnim prostorom, tj. (ne)mogućnošću financiranja postojećih i/ili povećanih rashoda države (Spilimbergo i sur., 2008.; IMF, 2010.).

Tako su mnoge zemlje EU-a (vidjeti Glassner, 2010. za detaljan pregled), ali i Hrvatska, poduzele restriktivne mjere $\mathrm{u}$ vezi sa zapošljavanjem i nagrađivanjem zaposlenih u javnom sektoru. Program gospodarskog oporavka Hrvatske, iz travnja 2010. godine (Vlada RH, 2010.), predviđa smanjenje broja zaposlenih u općoj državi otprilike za $5 \%$, uz uvođenje klauzule 2 za 1 (za dva otišla jedan novi zaposleni). Također, od izbijanja krize doneseno je niz odluka o smanjenju plaća ili drugih prava zaposlenika u javnom sektoru (vidjeti npr. Vlada RH, 2009., za sporazum o smanjenju plaća javnih službi), a koje uključuju i naputak Vlade o smanjenju plaća u javnim poduzećima. Iako ove promjene nisu toliko snažne kao što mnogi sudionici javne rasprave o ekonomskoj politici zagovaraju, može se pretpostaviti da je Vlada Republike Hrvatske imala na umu da snažniji reformski rezovi mogu dovesti do kratkoročnoga pada gospodarske aktivnosti.12 Program gospodarskog oporavka (Vlada RH, 2010.) također predviđa i skup drugih mjera s ciljem racionalizacije sustava javne uprave i povećanja efikasnosti u pružanju javnih usluga. ${ }^{13}$ Osim toga, iz nedavno objavljenih Smjernica ekonomske i fiskalne politike od 2012. do 2014. (Ministarstvo financija RH, 2011.; Novi list, 2011.), tj. iz projekcije povećanja ukupnih rashoda proračuna opće države do 2014. godine, implicitno proizlazi zamrzavanje mirovina i (ukupne mase) plaća zaposlenika op- 
će države, jer je već poznato da će na neke druge rashode (ponajprije izdvajanja za kamate za javni dug) nužno otići većina predviđenoga povećanja.

U članku se uspoređuje veličina hrvatskoga javnog sektora s veličinom javnih sektora drugih europskih zemalja (mjereno udjelom zaposlenih $\mathrm{u}$ javnom sektoru, tj. njegovim pojedinim segmentima, u ukupnom broju zaposlenih) te visina proračunskih rashoda opće države za naknade zaposlenima u odnosu na druge europske zemlje (mjereno udjelom rashoda opće države za naknade zaposlenima u BDP-u). Komparativna analiza pokazuje da prema većini upotrijebljenih pokazatelja Hrvatska nema prevelik javni sektor, osim kada je riječ o udjelu zaposlenih u javnim poduzećima u ukupnoj zaposlenosti. Relativno velika zaposlenost $\mathrm{u}$ javnim poduzećima, $\mathrm{uz}$ eventualno visoke plaće njihovih zaposlenika, mogu se negativno odraziti na ostatak gospodarstva, jer se djelatnosti javnih poduzeća mogu u relativno velikoj mjeri obavljati i u privatnom sektoru. Udio rashoda opće države za naknade zaposlenika u Hrvatskoj niži je od prosjeka zemalja EU-a, ali je u prve tri godine promatranog razdoblja bio viši od istovjetnog udjela u zemljama Srednje i Istočne Europe. Nadalje, udio ukupne potrošnje opće države u BDP-u za Hrvatsku niži je od istovjetnih udjela u zemljama EU-a i zemljama Srednje i Istočne Europe te je vrlo blizu empirijski procijenjenom optimalnom udjelu za deset zemalja Srednje i Istočne Europe.

Zbog recentnih recesijskih kretanja, Hrvatska je, kao i mnoge druge zemlje, bila prisiljena na fiskalnu konsolidaciju radi ograničena fiskalnog prostora, a s ciljem održavanja makroekonomske stabilnosti. Dio mjera odnosio se na smanjenje plaća i drugih prava zaposlenika u javnom sektoru, kao i na plan smanjenja broja zaposlenih, iako takve mjere najvjerojatnije imaju prociklični karakter, tj. kratkoročno produbljuju krizu. U relevantnim planovima Vlade intenzivno se govori i o potrebi reforme javnoga sektora s ciljem povećanja učinkovitosti. Čini se da se, iako deklarativno ispravne, ove mjere ne provode dovoljno brzo, pa da se time, uz izostanak ili sporu provedbu drugih potrebnih strukturnih reformi, propušta ubrzati oporavak gospodarstva, između ostalog i povećanjem fiskalnoga prostora, koji bi se mogao ostvariti slanjem jasnih reformskih signala vjerovnicima.

Unatoč teškom kriznom razdoblju i potrebnom zaustavljanju potencijalno neodrživih fiskalnih trendova, problemu zaposlenosti $\mathrm{u}$ javnom sektoru općenito treba pristupiti staloženo i objektivno te djelovati izvan dnevnopolitičkoga konteksta, a s ciljem unaprjeđenja čitavoga sustava na srednji i dugi rok. Pri tome treba staviti poseban naglasak na učinkovitost, koja ne ovisi isključivo o zaposlenima nego i o organi- 
DRUŠ. ISTRAŽ. ZAGREB GOD. 21 (2012), BR. $1(115)$

STR. 101-119

BEJAKOVIĆ, P., BRATIĆ V., VUKŠIĆ, G.: KOMPARATIVNA.. zaciji, upravljanju, sustavu nagrađivanja itd. Kratkoročnim, a odveć restriktivnim, mjerama može se, s jedne strane, trajno naštetiti kvaliteti usluga koje javni sektor pruža, ako to dovede do odlaska kvalitetnijih zaposlenika, dok se, s druge strane, preekspanzivnom politikom plaća i novoga zapošljavanja može ugroziti financijska stabilnost javnoga sektora, pa i čitavoga gospodarstva.

Također, ako bi se pribjeglo smanjenju broja zaposlenih $\mathrm{u}$ nekim segmentima javnoga sektora, npr. podugovaranjem uz pretpostavku veće učinkovitosti privatnoga sektora, treba pratiti poboljšava li se time omjer kvalitete usluga prepuštenih privatnom sektoru i njihove cijene. To u velikoj mjeri ovisi o dobiti koju privatno poduzeće želi ostvariti kroz tu djelatnost te o intenzitetu konkurencije i transparentnosti u postupcima javne nabave kod odabira privatnih pružatelja usluga koje trenutno obavlja javni sektor.

$\mathrm{S}$ obzirom na relativno malen udio zaposlenih u područjima javne uprave, obrazovanja i zdravstva u ukupnoj zaposlenosti u Hrvatskoj, a u odnosu na druge europske zemlje, treba voditi računa da smanjenjem broja zaposlenih u javnom sektoru u ovim područjima ne bi došlo do još veće razlike. Ako glasači izraze takve preferencije, pa nositelji ekonomsko-političkih odluka krenu u tom smjeru, treba imati na umu da bi to možda značilo izostavljanje dijela populacije iz skupine onih kojima su, npr. obrazovne i zdravstvene, usluge dostupne, i/ili bi razina kvalitete javnih usluga bila umanjena.

\section{BILJEŠKE}

1 Za detaljniji pregled vidjeti npr. Pevcin (2004.a).

2 Pevcin (2004.a) pronalazi negativnu vezu razine državne regulacije gospodarskih aktivnosti i udjela rashoda države u BDP-u.

${ }^{3}$ Na sličan način utječe i razvijenost nevladina sektora i/ili civilnoga društva: u zemljama gdje je taj sektor razvijen, država mu može prepustiti dio usluga u socijalnoj skrbi, obrazovanju i/ili zdravstvenoj zaštiti, čime se dodatno smanjuje broj zaposlenih u državnom sektoru.

4 Sličan pristup slijede i neke druge studije o zaposlenosti u javnom sektoru (vidi npr. Glassner, 2010.). Treba napomenuti da ILO za neke zemlje uzima podatke o ukupnoj zaposlenosti na području Javna uprava i obrana, obvezno socijalno osiguranje, za procjenu broja zaposlenih u općoj državi, iako to vjerojatno podcjenjuje njihov ukupni broj (Hammouya, 1999., 5). Za tri takve zemlje u usporedbi koja slijedi prema podacima ILO-a o zaposlenosti u općoj državi podaci nisu prikazani, uz napomenu da su nepouzdani.

5 Podatak ILO-a o zaposlenosti u sektoru opće države i u javnim poduzećima za Hrvatsku te podatak DZS-a o broju zaposlenih u kategoriji: državni sektor i sektor u pretvorbi rezultat su iste ankete o radnoj snazi, pri čemu je jedina razlika u nazivu te kategorije zaposlenih. 
DRUŠ. ISTRAŽ. ZAGREB GOD. 21 (2012),

BR. 1 (115)

STR. 101-119

BEJAKOVIĆ, P., BRATIĆ, V., VUKŠIĆ, G.:

KOMPARATIVNA.
${ }^{6} \mathrm{Za}$ razdoblje nakon 2008. godine nema podataka u bazi ILO-a, a podaci o zaposlenosti po pojedinim područjima NKD-a nisu usporedivi s ranijim razdobljem zbog promjene metodologije klasifikacije (vidi također Glassner, 2010.)

7 Potrebno je spomenuti da su podaci ILO-a za različite zemlje prikupljeni iz različitih izvora, pa su i jedinice u kojima je zaposlenost izražena također različite (vidjeti napomene ispod tablice). Važno je naglasiti da je uvijek ista metoda primijenjena i za procjenu ukupne zaposlenosti, pa je mogućnost značajnije pogreške smanjena zbog jednakoga metodološkog pristupa u određivanju brojnika i nazivnika opisanih omjera.

8 Budući da naknade za zaposlene sadrže i poreze i doprinose koji se najvećim dijelom uplaćuju natrag u državni proračun, bolji uvid ostvario bi se usporedbom rashoda za neto plaće financirane iz proračuna opće države. Ovi podaci, nažalost, nisu dostupni. Za nešto manji broj zemalja postoje podaci o rashodima za plaće opće konsolidirane države u BDP-u, a koji su, zapravo, rashodi za naknade zaposlenima umanjeni za socijalne doprinose poslodavca. Ova informacija, međutim, još uvijek nije dovoljna, jer nema dovoljno preciznih i usporedivih podataka o prosječnim iznosima poreza na dohodak i doprinosa posloprimaca.

${ }^{9}$ Izračun u Nestić (2005.) temelji se na podacima iz Ankete o radnoj snazi iz 2003. godine. Međutim, u recentnim izjavama čelnika dijela sindikata javnih službi navodi se da je utvrđeno kako plaće $u$ javnom sektoru zaostaju za onima u privatnom za 2-3\% (Index.hr, 2011.).

10 Pritom se ne ulazi u različitu strukturu državnih rashoda i njezinu optimalnost $\mathrm{u}$ kontekstu maksimiziranja gospodarskog rasta, kao ni u učinkovitost rashoda u smislu njihove ekonomičnosti, koja često može biti narušena npr. koruptivnim aktivnostima.

11 Do sličnog zaključka dolazi i Cavallo (2005.), pri čemu naglašava da povećana zaposlenost $\mathrm{u}$ javnom sektoru djeluje na sličan način kao i proračunski transferi kućanstvima.

12 Ova mogućnost još je uvijek aktualna, kao što se navodi u recentnoj publikaciji Ekonomskog instituta (2011.).

13 Vlada Republike Hrvatske u ožujku 2008. godine donijela je Strategiju reforme javne uprave od 2008. do 2011. Kao što se navodi u Jurinjak (2009.), reforma se sustavno provodila i prije donošenja Strategije, a prijašnji rezultati navode se u samoj Strategiji. Treba, međutim, biti svjestan poteškoća u samoj provedbi Strategije (vidjeti npr. Banka, 2011., o prestanku postojanja Vijeća za koordinaciju osnovanog pri donošenju Strategije, već šest mjeseci nakon osnivanja).

Alesina, A. i Wacziarg, R. (1998.), Openness, Country Size and the Government. Journal of Public Economics, 69 (3): 305-321. doi:10.1016/ S0047-2727(98)00010-3

Algan, Y., Cahuc, P. i Zylberberg, A. (2002.), Public Employment and Labour Market Performance. Economic Policy, 17 (34): 7-66. doi:10.1111/ 1468-0327.00083

Banka (2011.), David Blunt: Od Hrvatske će se strogo tražiti reforma javne uprave, Dostupno na: http://www.bankamagazine.hr/Naslovnica/ 
DRUŠ. ISTRAŽ. ZAGREB GOD. 21 (2012), BR. 1 (115)

STR. 101-119

BEJAKOVIĆ, P., BRATIĆ, V., VUKŠIĆ, G.: KOMPARATIVNA..
Hrvatska/tabid/102/View/Details/ItemID/67533/rbpid/255f2e07-6c604efa-b9e7-d49bfb7bd721/Default.aspx

Barro, R. J. (1990.), Government Spending in a Simple Model of Endogenous Growth. Journal of Political Economy, 98 (5): S103-S125. doi: $10.1086 / 261726$

Cavallo, M. (2005.), Government Employment Expenditure and the Effects of Fiscal Policy Shocks. Federal Reserve of San Francisco Working Paper No. 2005-16.

Drewry, G. (1999.), The Citizen and the New Contractual Public Management: The Quest for New Forms of Accountability and a New Public Law. U: Y. Fortin i H. Van Hassel (ur.), Contracting in the New Public Management: From Economics to Law and Citizenship, Amsterdam: IOS Press.

DZS (2009.), Statistički ljetopis 2009, Zagreb, Državni zavod za statistiku.

Ekonomski institut (2011.), Priopćenje za javnost u povodu objavljivanja novog broja publikacije Croatian Economic Outlook Quarterly (broj 47, srpanj 2011.), Ekonomski institut, Zagreb. Dostupno na: http://www. eizg.hr/croatian-economic-outlook-quarterly-hr-HR/25.aspx

Finn, M. G. (1998.), Cyclical Effects of Government's Employment and Goods Purchases. International Economic Review, 39 (3): 635-657. doi:10.2307/2527394

Glassner, V. (2010.), The Public Sector in Crisis, ETUI Working Paper 2010.07. December 2010.

Gomes, P. (2010.), Fiscal Policy and the Labour Market: The Effects of Public Sector Employment and Wages, IZA Discussion Paper No. 5321.

Hammouya, M. (1999.), Statistics on Public Sector Employment: Methodology, Structures and Trends, Geneva, International Labour Office Working Papers.

Hoffmann, E. (2002.), Statistics on Public Sector Employment: A Review of Quality Issues, Stockholm: 27th General Conference of the International Association for Research in Income and Wealth. Dostupno na: http:/unpan1.un.org/intradoc/groups/public/documents/ ilo/unpan009522.pdf

IMF (2010.), From Stimulus to Consolidation: Revenue and Expenditure Policies in Advanced and Emerging Economies, Fiscal Affairs Department, Washington DC.

Index.hr (2011.), Vlada zamrzava mirovine i plaće do 2014. godine. Dostupno na: http://www.index.hr/vijesti/clanak/vlada-zamrzava-mirovinei-place-do-2014-godine/564044.aspx

Jurinjak, J. (2009.), Glavni rezultati provedbe Strategije reforme državne uprave za razdoblje 2008.-2011. Hrvatska javna uprava, 9 (1): 29-43.

Jutarnji list (2010.a), Zbog enormne potrošnje država pred bankrotom. Vladu nije briga! Dostupno na: http://www.jutarnji.hr/zbog-enormnepotrosnje-drzava-pred-bankrotom--vladu-nije-briga-/572820/

Jutarnji list (2010.b), Divovski javni sektor: za državu radi skoro svaki treći zaposleni. Dostupno na: http://www.jutarnji.hr/za-drzavu-radiskoro-svaki-treci-zaposleni-/876042/ 
DRUŠ. ISTRAŽ. ZAGREB GOD. 21 (2012),

BR. 1 (115),

STR. 101-119

BEJAKOVIĆ, P., BRATIĆ, V., VUKŠIĆ, G.: KOMPARATIVNA.
Karras, G. (1997.), On the Optimal Government Size in Europe: Theory and Empirical Evidence. The Manchester School, 65 (3): 280-294. doi:10.1111/1467-9957.00057

Linnemann, L. (2009.), Macroeconomic Effects of Shocks to Public Employment. Journal of Macroeconomics, 31 (2): 252-267. doi:10.1016/ j.jmacro.2008.09.004

Magazzino, C. i Forte, F. (2010.), Optimal Size of Government and Economic Growth in EU-27, MPRA Paper No. 26669, November 2010.

Ministarstvo financija Republike Hrvatske (2011.), Smjernice ekonomske i fiskalne politike za razdoblje 2012-2014, Ministarstvo financija Republike Hrvatske. Dostupno na: http://www.mfin.hr/hr/smjerniceekonomske-i-fiskalne-politike

Nestić, D. (2005.), The Determinants of Wages in Croatia: Evidence from Earnings Regressions. U: 65th Anniversary Conference of the Institute of Economics (str. 131-162), Zagreb, Proceedings, Zagreb, Institute of Economics.

Novi list (2011.), Vlada zaleđuje mirovine i plaće za 1,5 milijuna građana do 2014. godine. Dostupno na: http://www.novilist.hr/Vijesti/ Hrvatska/Vlada-zaleduje-mirovine-i-place-za-1-5-milijuna-gradanado-2014.-godine

Nowotny, E. (1996.), Der Öffentliche Sektor, Heidelberg, New York, Berlin, Springer-Verlag.

Pevcin, P. (2004.a), Cross-Country Differences in Government Sector Activities. Zbornik radova Ekonomskog fakulteta Sveučilišta u Rijeci, 22 (2): 41-59.

Pevcin, P. (2004.b), Does Optimal Size of Government Spending Exist? Rad prezentiran na konferenciji EGPA u Ljubljani, rujan 2004. Dostupno na: http://soc.kuleuven.be/io/egpa/fin/paper/slov2004/pevcin.pdf Spilimbergo, A., Symansky, S., Blanchard, O. i Cottarelli, C. (2008.), Fiscal Policy for the Crisis, IMF Staff Position Note SPN/08/01, December 2008.

United Nations (1993.), System of National Accounts 1993, New York, United Nations.

Vlada Republike Hrvatske (2009.), Sporazum o plaćama javnih službi. Dostupno na: http://www.vlada.hr/hr/naslovnica/novosti i najave/2009/ svibanj/vlada_i_sindikati_javnih_sluzbi_parafirali_sporazum_o_pla cama_strajk_se_obustavlja

Vlada Republike Hrvatske (2010.), Program gospodarskog oporavka. Dostupno na: http://www.vlada.hr/hr/naslovnica/novosti_i_najave/2010/ travanj/predsjednica_vlade_predstavila_program_gospodarskog_o poravka

Zimmermann, H. i Henke, K. D. (1994.), Finanzwissenschaft, München, Verlag Franz Vahlen. 
DRUŠ. ISTRAŽ. ZAGREB GOD. 21 (2012), BR. 1 (115)

STR. 101-119

BEJAKOVIĆ, P., BRATIĆ V., VUKŠIĆ, G.:

KOMPARATIVNA.

\section{International Comparison of Employment and Compensation of Employees in the Public Sector of Croatia and European Union}

Predrag BEJAKOVIĆ, Vjekoslav BRATIĆ, Goran VUKŠIĆ Institute of Public Finance, Zagreb

This article compares the size of the Croatian public sector with public sectors of EU countries, using several indicators of public sector employment (i.e. its segments) and general government expenditure. Data is discussed from the perspective of potentially too big a public sector, as well as in the short-term context of the recent crisis and its impact on employment and general economic situation. Comparative analysis shows that most indicators imply that the Croatian public sector is not too big, except for the share of public enterprises' employees in total employment. The share of the general government budget expenditures for compensation of employees in GDP in Croatia is lower than the average share of EU countries, but it was a little higher than the average share of countries of Central and Eastern Europe over the first three years of the observed period. The share of total general government expenditures in GDP in Croatia is lower than the corresponding shares in EU and Central and Eastern European countries. Due to the effects of the crisis in Croatia, some restrictive measures regarding the wages and employment in the public sector have been implemented and/or planned. Along with the necessary containment of the potentially unsustainable fiscal trends, the problem of public sector employment should be approached with an emphasis on increased efficiency.

Keywords: Croatia, employment, public sector, international comparison 